\title{
ECOLOGICAL IMPLICATIONS OF BOVINE TUBERCULOSIS IN AFRICAN BUFFALO HERDS
}

\author{
Alex Caron, ${ }^{1}$ Paul C. Cross,,$^{1,2}$ And Johan T. Du ToiT ${ }^{1,3}$ \\ ${ }^{1}$ Mammal Research Institute, Department of Zoology and Entomology, University of Pretoria, Pretoria 2002, South Africa \\ ${ }^{2}$ Department of Environmental Science, Policy and Management, University of California 201 Wellman Hall no. 3112, \\ Berkeley, California 94720-3112 USA
}

\begin{abstract}
Following the recent invasion of bovine tuberculosis (BTB) into the Kruger National Park, South Africa, we conducted a study on the maintenance host, African buffalo, to investigate associations between BTB prevalence and calf:cow ratio, age structure, body condition, and endoparasite load. Statistical analyses compared herds of zero, medium (1$40 \%)$, and high $(>40 \%)$ BTB prevalence. To control for ecological variation across the park we collected data in northern, central, and southern regions and restricted some analyses to particular regions of the park. Body condition declined over the course of the 2001 dry season, and buffaloes in the southern region of the park, with the highest BTB prevalence, were in worse condition than buffaloes in the northern region (which receives less annual rainfall but is still virtually BTB-free). Herd-level analyses of the entire park, the south and central regions, and just the southern region all indicated that herds of higher BTB prevalence were in worse condition and lost condition faster through the dry season than herds of lower BTB prevalence. Fecal endoparasite egg counts increased during the dry season and were associated with both decreased body condition and increased BTB prevalence. Although we did not detect any obvious effect of BTB on the age structure of the buffalo population, our findings indicate early symptoms of wider scale BTB-related ecological disturbances: buffalo herds with high BTB prevalence appear more vulnerable to drought (because of a decrease in body condition and an increase in endoparasite load), and because lions selectively kill weak buffaloes their prey base is accumulating a disproportionately high prevalence of BTB, to which lions are susceptible.
\end{abstract}

Key words: body condition; bovine tuberculosis; endoparasites; Kruger National Park; Mycobacterium bovis; Syncerus caffer; South Africa; wildlife disease.

\section{INTRODUCTION}

Understanding the dynamics of African savannas over the past century requires an understanding of the effects of cattleborne diseases on indigenous ungulates. For example, the rinderpest pandemic of the 1890s triggered a succession of ecological disturbances that reverberated across the continent and have yet to equilibrate even in large national parks such as Serengeti in Tanzania (Sinclair 1979), Chobe in Botswana (Walker 1989, Mosugelo et al. 2002), and Kruger in South Africa (Bengis et al. 2003). With rinderpest the course of the disease through populations and its spread across species were inferred post hoc from anecdotal records. Indeed, few studies have monitored an exotic disease as it invades a naïve and natural population. In this paper we document some ecological symptoms of bovine tuberculosis (BTB, caused by Mycobacterium bovis) as it invades the African buffalo (Syncerus caffer) population of Kruger National Park, one of the world's largest and oldest national parks.

Manuscript received 13 August 2002; revised 18 December 2002; accepted 9 January 2003. Corresponding Editor: R. S Ostfeld.

${ }^{3}$ Corresponding author: E-mail: jtdutoit@zoology.up.ac.za
BTB occurs worldwide and can be controlled in cattle with test-and-slaughter programs (Krebs et al. 1998, Kao and Roberts 1999), but this has not been successful in areas where wildlife species are reservoir hosts (Schmitt et al. 1997, Bruning-Fann et al. 1998). There is circumstantial evidence that BTB entered Kruger either in the early 1960 s or early 1980 s when there were BTB outbreaks in the cattle population along the southern border of the park (Bengis et al. 1996), and the spatial and temporal distribution of BTB within Kruger supports this theory (Rodwell et al. 2000). BTB remained undetected until 1990, however, despite the routine inspection of over 8000 culled buffalo from 1970 to 1980 and an intensive survey of diseases of buffalo in the southern area of Kruger (Basson et al. 1970).

Buffalo now appears to be the reservoir host for BTB in Kruger (Rodwell et al. 2000, Bengis et al. 2003), but the disease is spreading to other species. Since 1990 it has been found in lions (Panthera leo), leopards (Panthera pardus), cheetahs (Acinonyx jubatus), greater kudus (Tragelaphus strepsiceros), and chacma baboons (Papio ursinus) within the park (Keet et al. 1996, 2000, 2001). Despite limited information, park managers must soon decide on a BTB strategy, which could be either extensive buffalo culling, imposing a buffalo 
free zone (involving a fenced cordon and/or intensive local culling) to protect uninfected herds, vaccination, some combination thereof, or nothing (de Vos et al. 2001). Pressure is mounting for a practical and sustainable strategy because the implications of the BTB epidemic transcend ecosystem conservation in Kruger. They include the security of the South African livestock industry outside the park, the political acceptance of transfrontier conservation management along Kruger's boundaries with Mozambique and Zimbabwe, and the maintenance of genetic connectivity between wildlife subpopulations across southern Africa.

Rodwell et al. $(2000,2001)$ have conducted the most definitive work to date on the epidemiology of BTB in Kruger. Their sampling of the buffalo population in 1991, 1992, and 1998 indicated that BTB was increasing in prevalence and spreading northward through the park. From postmortem examinations of over 600 shot buffaloes in 1998 they divided the park into southern, central, and northern regions based upon BTB prevalence. The southern region had an average herd prevalence of $38 \%$, while in the central and northern regions the prevalence levels were $16 \%$ and $1.5 \%$, respectively (Rodwell et al. 2000; Fig.1). The age structure of the sampled animals suggested that BTB might be increasing the mortality rate of the older age classes in the high-prevalence southern region. However, BTB is a chronic bacterial disease that persists for years in infected maintenance hosts (Morris et al. 1994), and for the Kruger buffaloes it has been unclear if BTB significantly increases an infected animal's susceptibility to morbidity-related agents such parasitism, predation, or drought. We hypothesized that BTB does have such effects and we tested the following predictions using noninvasive techniques: (1) buffaloes in a region (as defined by Rodwell et al. 2001) of high BTB prevalence will generally display worse body condition, have higher fecal endoparasite counts, and include a lower proportion of old individuals than in regions of lower BTB prevalence; (2) within regions, herd-level analyses will show similar relationships with respect to body condition, endoparasite loads, and age structure, with animals in high prevalence herds being in worse body condition; and (3) as the dry season progresses these indicators will become more pronounced in regions and herds with higher BTB prevalence.

\section{Materials and Methods}

Field data were collected in the Kruger National Park from July to September 2001. The park (situated between $22^{\circ} 31^{\prime} \mathrm{S}$ and $25^{\circ} 31^{\prime} \mathrm{S}, 30^{\circ} 45^{\prime} \mathrm{E}$ and $32^{\circ} 00^{\prime} \mathrm{E}$, covering some $20000 \mathrm{~km}^{2}$ ) is roughly divided down the middle (Fig. 1) into a western half on granitic soil and an eastern half on predominantly basaltic clay (with the exception of the Lebombo Mountains in the extreme east, which are composed of rhyolite). Superimposed on this east-west variation in soil type is a south-north variation in mean annual rainfall, ranging from $\sim 700$

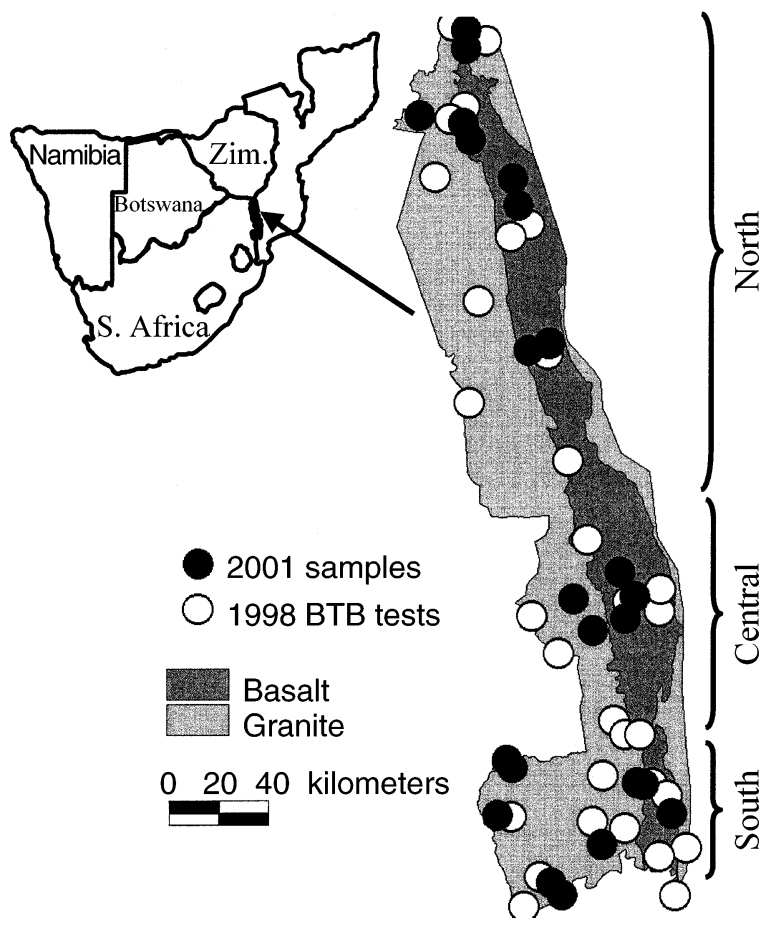

FIG. 1. Map showing the location of the Kruger National Park in southern Africa, regional divisions of Kruger (north, central, south) used in our analysis, and the distribution of soils derived from granite and basalt parent rock. The soils along the eastern boundary of Kruger are derived from rhyolite but are more similar to the granitic than the basaltic soils. Locations are indicated for buffalo herds sampled for bovine tuberculosis (BTB) testing in 1998 (open circles) and for this study in 2001 (closed circles).

$\mathrm{mm}$ in the extreme southwest to $\sim 400 \mathrm{~mm}$ in the northern plains (Gertenbach 1983). Vegetation in the south is dominated by mixed Combretum woodland and thickets, in the central region by mixed Combretum woodland (on the granite and rhyolite) and Acacia nigrescens/Sclerocarya birrea savanna (on the basalt), and in the northern region by Colophospermum mopane shrubland and sandveld vegetation (Gertenbach 1983). These ecological differences between the southern, central, and northern regions of the park could confound park-wide population-level analyses of BTB impact (e.g., Rodwell et al. 2001), so we controlled for regional differences by comparing buffalo herds of different BTB prevalence within regions.

The dry season (June to November in Kruger) is when resources become limited for buffalo (Sinclair 1977, Prins 1996) so we concentrated our data collection during this period, when we predicted that BTBinduced morbidity would compound nutrient limitation and have its greatest impact on the condition of infected animals. We observed and video recorded a total of 31 buffalo herds as they crossed roads or open areas. Sampling was repeated twice, once in July and once in September, to compare the condition of herds in the 
early and late phases of the dry season. During each sampling session herds were located opportunistically for 5-8 days per region, yielding 4-6 herds per region during each phase of the dry season.

\section{Age structure and calf:cow ratio}

Animals were placed into five age classes (0-1 yr, 1-3 yr, 3-5 yr, 5-8 yr, and >8 yr) using body size, horn development and wear and, in the case of males, dewlap and testicle size (Pienaar 1969, Grimsdell 1973, Sinclair 1977). Gender was recorded for the last two age classes. Calf:cow ratio was calculated as the ratio of all animals in the $0-1 \mathrm{yr}$ class to females in the $>5$ yr classes. Due to high variability in the presence or absence of bachelor groups within breeding herds it was not possible to accurately estimate adult sex ratio using the herd data. Playbacks of video recordings were used to derive an estimate of age structure for each herd by classifying all clearly visible animals. If a herd was found in September at a location $<10 \mathrm{~km}$ from where a herd had been found in July it was assumed to be the same herd, in which case the age structure data were pooled for that herd.

\section{Body condition}

We noted the age and condition of all individuals whose complete body was visible on the video recordings. Our body condition index was adapted from Prins (1996) and ranged from 1 (poor) to 5 (good) based on a visual assessment of skeletal protrusion around the pelvis, flank, ribs, neck, and spine. Half-points were used to increase precision. Since body condition is related to age and sex, we derived an estimate of herd condition from the arithmetic mean condition index of females in $>5$-yr age classes.

\section{Endoparasite load}

A modified McMaster egg-counting method (Raynaud 1970, Thienpont et al. 1986, Ward et al. 1997) was used to estimate endoparasite load from fresh fecal samples: dung pats were sampled on the ground (30 separate dung pats per herd) within two hours of deposition; samples were stored at $2-4^{\circ} \mathrm{C}$ for $12-48 \mathrm{~h}$ after collection; subsamples were mixed with a dense liquid $\left(\mathrm{MgSO}_{4} \cdot 7 \mathrm{H}_{2} \mathrm{O}\right)$ for flotation of endoparasite eggs; $70 \mathrm{~mL}$ of this mixture was placed on a McMaster slide and all eggs were counted under a microscope. The 30 samples per herd were divided by means of random allocation into six groups and each was mixed separately to make six composite samples per herd, which dampened individual variability and maximized herd coverage per unit sampling effort (Ward et al. 1997). The largest dung pats ( $>25 \mathrm{~cm}$ in diameter) were sampled to include as many adults as possible. The McMaster slide was composed of three chambers and for each composite analysis the three chambers were read completely (not only the grids). The sum of the counts in the three chambers was used for statistical analysis. For the main analyses, only the Trichostrongylus-type eggs were used (85-100 $\mu \mathrm{m}$ long, including Trichostrongylus spp. as well as Cooperia spp., Haemonchus spp., Ostertagia spp., and Oesophagostumum spp.; see Thienpont et al. 1986). Because most of the other egg species were rare we used logistic regression to identify those factors that explained variability in the presence or absence of multiple egg types (composite samples scored zero if they contained only Trichonstrongylus-type eggs or one if they contained at least one other species).

\section{Statistical analyses}

Because BTB is spreading northward from its origin in the southeast corner of the park, there are no herds in the south without BTB and there are very few herds in the north with BTB. We therefore conducted statistical analyses at both regional and herd levels. The regional-level analysis compared the three prevalence regions (Fig. 1) and allowed us to compare our results with those of Rodwell et al. (2001). We then attempted to control for regional effects using herd-level analyses, which compared herds of different BTB prevalence across: (1) all regions of the park; (2) central and southern regions; and (3) the southern region only. Since 1998 was the most recent BTB testing, we matched herds sampled in 2001 to those tested in 1998 based upon the nearest neighbor distance and used the ВТВ prevalence of the nearest herd sampled in 1998 as the best estimate of current prevalence (Fig. 1). From these estimates three prevalence categories were derived: zero, medium $(1-40 \%)$, and high $(>40 \%)$. Our data from the Satara region of Kruger, as well as those of Sinclair (1977) from Serengeti and Prins (1996) from Lake Manyara, suggest that buffalo home ranges remain consistent from year to year. Furthermore, the slow and chronic nature of BTB infection makes it unlikely for BTB prevalence to fluctuate widely between years (Rodwell et al. 2000). We therefore assumed that the prevalence estimates made at specific locations in 1998 were still adequately reliable for deriving a relative index of BTB prevalence in herds nearest to those locations in 2001. All statistical analyses were conducted using Statistica (StatSoft 1991).

\section{RESULTS}

\section{Age structure and calf: cow ratio}

The age structure of buffalo herds was found to vary significantly across regions, with particular variation occurring in the $1-3$ yr class $\left(\chi^{2}=23.1, \mathrm{df}=8, P=\right.$ 0.003 , Fig. 2). There appeared to be fewer juveniles in the southern region than in the central and northern regions; however, the herd-level analysis (using a loglinear analysis) found no significant interaction between the frequency of each age class and BTB prevalence category $\left(\chi^{2}=12.9\right.$, $\left.\mathrm{df}=8, P=0.12\right)$. This result also applied when we limited the herd-level anal- 


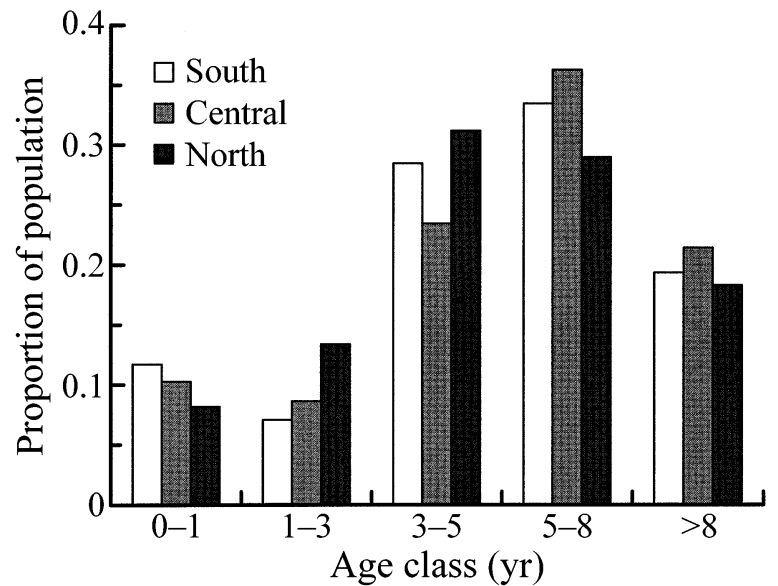

FIG. 2. The regional age structure of the buffalo population in the Kruger National Park. Age classes were determined visually from video recordings taken from July to September 2001.

ysis to just the southern region $\left(\chi^{2}=3.84\right.$, df $=4, P$ $=0.43)$. Finally, there was no significant variation in calf:cow ratio across the three regions (one-way ANOVA, df $=2, P=0.675)$.

\section{Body condition}

Buffalo body condition decreased on average, across all age-sex classes and regions, as the dry season progressed (Table 1, Fig. 3) from a condition index of 3.21 \pm 0.024 (mean $\pm 1 \mathrm{SE}$ ) in the early dry season to 2.92 \pm 0.026 in the late dry season. The same pattern applied for adult females only (condition indices decreased from $3.20 \pm 0.040$ to $2.87 \pm 0.027$ ). Buffaloes in the southern region were always in worse condition than those in the central region, while those in the northern region were in the best condition, regardless of season (Table 1, Fig. 3). Body condition in the south

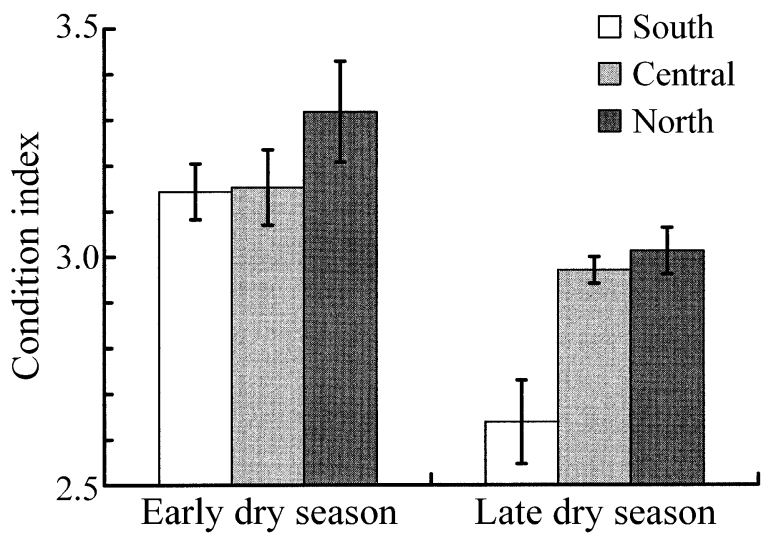

FIG. 3. Mean herd condition (bars indicate $\pm 1 \mathrm{SE}$ ) in the early and late dry season in the northern, central, and southern regions of Kruger. Mean herd condition was based upon a visual assessment of females in the $>5-y r$ age classes.

decreased faster through the dry season than in the other regions. Since the age distribution for each region could influence mean body condition, we focused on adult females as an indicator of herd condition. Herdlevel analyses indicated that herds with high BTB prevalence were in the worst condition in the late dry season and lost condition faster (i.e., mean condition index dropped more during the same period) than those with low or zero BTB prevalence (Table 1, Fig. 4a). To separate the effects of BTB prevalence and region we limited later analyses to one or two regions only and found that body condition was still worse in herds with high BTB prevalence (Table 1, Fig. 4b). We found similar results when we included the data from all age and sex classes.

\section{Endoparasite load}

The endoparasite eggs seen during the 180 analyses conducted for this study were mostly Trichostrongylus-

TABLE 1. Results of herd condition analyses using two-way ANOVA on the African buffalo herd in Kruger National Park, South Africa.

\begin{tabular}{|c|c|c|c|c|c|c|}
\hline Analysis & Factors & $\begin{array}{c}\text { Herds } \\
\text { (no.) }\end{array}$ & $\begin{array}{c}\mathrm{df} \\
\text { effect }\end{array}$ & $\begin{array}{c}\text { MS } \\
\text { effect }\end{array}$ & $F$ & $P$ \\
\hline Regional & $\begin{array}{l}\text { season } \\
\text { region } \\
\text { region } \times \text { season } \\
\text { error }\end{array}$ & 27 & $\begin{array}{r}1 \\
2 \\
2 \\
21\end{array}$ & $\begin{array}{l}0.70 \\
0.19 \\
0.06\end{array}$ & $\begin{array}{r}26.12 \\
7.07 \\
2.20\end{array}$ & $\begin{array}{r}<0.001 \\
0.004 \\
0.136\end{array}$ \\
\hline Herd level (all regions) & $\begin{array}{l}\text { season } \\
\text { prevalence } \\
\text { season } \times \text { prevalence } \\
\text { error }\end{array}$ & 27 & $\begin{array}{r}1 \\
2 \\
2 \\
21\end{array}$ & $\begin{array}{l}0.915 \\
0.132 \\
0.116\end{array}$ & $\begin{array}{r}42.77 \\
6.19 \\
5.40\end{array}$ & $\begin{array}{r}<0.001 \\
0.008 \\
0.013\end{array}$ \\
\hline Herd level (central and southern regions) & $\begin{array}{l}\text { season } \\
\text { prevalence } \\
\text { season } \times \text { prevalence } \\
\text { error }\end{array}$ & 18 & $\begin{array}{r}1 \\
2 \\
2 \\
12\end{array}$ & $\begin{array}{l}0.577 \\
0.045 \\
0.116\end{array}$ & $\begin{array}{r}31.72 \\
2.48 \\
6.35\end{array}$ & $\begin{array}{r}<0.001 \\
0.126 \\
0.013\end{array}$ \\
\hline Herd level (southern region only) & $\begin{array}{l}\text { season } \\
\text { prevalence } \\
\text { season } \times \text { prevalence } \\
\text { error }\end{array}$ & 11 & $\begin{array}{l}1 \\
1 \\
1 \\
7\end{array}$ & $\begin{array}{l}0.619 \\
0.024 \\
0.145\end{array}$ & $\begin{array}{r}37.18 \\
1.45 \\
8.72\end{array}$ & $\begin{array}{r}<0.001 \\
0.268 \\
0.021\end{array}$ \\
\hline
\end{tabular}



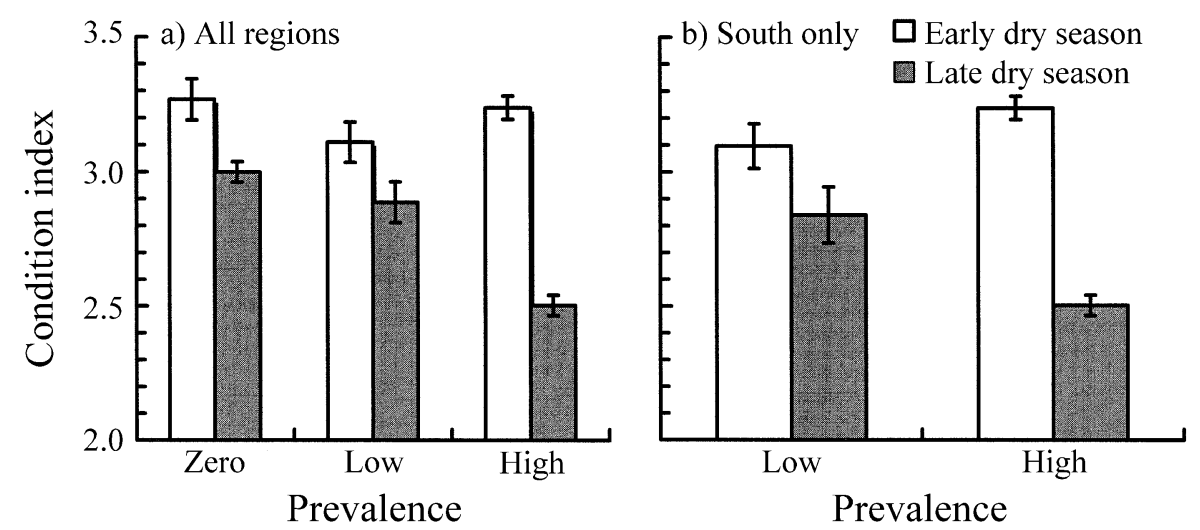

FIG. 4. Herd-level analyses of mean condition $( \pm 1 \mathrm{SE})$ in the early and late dry season in herds of zero, medium (1$40 \%$ ), and high (40+\%) BTB prevalence based on (a) all regions of Kruger and (b) herds in the southern region only.

type, with some rare Trichuris spp. and Fasciola spp. There was a significant seasonal effect, with more eggs excreted at the end of the dry season than at the beginning (Table 2, Fig. 5). The density of eggs in feces (mean $\pm 1 \mathrm{SE})$ varied between $298 \pm 23.3 \mathrm{eggs} / \mathrm{g}$ (range: $0-1100$ eggs/g) in the early dry season and 409 $\pm 28.7 \mathrm{eggs} / \mathrm{g}$ (range: $0-1233 \mathrm{eggs} / \mathrm{g}$ ) in the late dry season. There was a strong overall relationship between average herd condition and endoparasite load (Fig. 6), and when we split the data by seasonal phase we found that the significance of the relationship emerged in the late dry season $(P<0.05)$. Fecal egg counts appeared to increase more in the southern region, and the statistical interaction of region and endoparasite load was close to significant ( $P=0.067$, Table 2, Fig. 5). Our park-wide analysis indicated that herds with high BTB prevalence underwent the greatest increase in endoparasite load and the greatest decrease in body condition between early and late phases of the dry season $(P=0.017$, Table 2$)$. According to herd locations and geological mapping, we assigned herds to either gra- nitic or basaltic substrates (Fig. 1). Fecal egg counts in the dystrophic granitic soils increased more than in the eutrophic basaltic soils (Table 2), which mirrored the lower body condition of buffalo on granitic soils during the late dry season. The body condition index of herds on granitic soil decreased from 3.21 to 2.79 compared to herds on basalt, which decreased from 3.18 to 2.94 , during the dry season. The effect of soil type on herd condition was not statistically significant however, in a two-way ANOVA with time as the second independent variable. There was no difference in the multiparasite analysis between seasonal phases (logistic regression: $\chi^{2}=0.267, P=0.605$ ) indicating that the mix of endoparasite species did not vary through the dry season.

\section{DISCUSSION}

At regional and herd levels our analyses suggest that an increase in BTB prevalence among Kruger buffaloes is associated with a decrease in overall body condition. At the regional level there was a gradient of decreasing

TABLE 2. Results of the endoparasite analyses on African buffalo using two-way ANOVA.

\begin{tabular}{|c|c|c|c|c|c|c|}
\hline Analysis & Factors & $\begin{array}{c}\text { Herds } \\
\text { (no.) }\end{array}$ & $\begin{array}{c}\text { df } \\
\text { effect }\end{array}$ & $\begin{array}{c}\text { MS } \\
\text { effect }\end{array}$ & $F$ & $P$ \\
\hline Regional & $\begin{array}{l}\text { season } \\
\text { region } \\
\text { region } \times \text { season } \\
\text { error }\end{array}$ & 25 & $\begin{array}{r}1 \\
2 \\
2 \\
19\end{array}$ & $\begin{array}{r}86.67 \\
7.64 \\
25.92\end{array}$ & $\begin{array}{r}10.48 \\
0.92 \\
3.14\end{array}$ & $\begin{array}{l}0.004 \\
0.414 \\
0.067\end{array}$ \\
\hline Herd level (all regions) & $\begin{array}{l}\text { season } \\
\text { prevalence } \\
\text { season } \times \text { prevalence } \\
\text { error }\end{array}$ & 25 & $\begin{array}{r}1 \\
2 \\
2 \\
19\end{array}$ & $\begin{array}{r}134.56 \\
0.92 \\
37.72\end{array}$ & $\begin{array}{r}18.21 \\
0.12 \\
5.11\end{array}$ & $\begin{array}{r}<0.001 \\
0.883 \\
0.017\end{array}$ \\
\hline Herd level (southern region only) & $\begin{array}{l}\text { season } \\
\text { prevalence } \\
\text { season } \times \text { prevalence } \\
\text { error }\end{array}$ & 10 & $\begin{array}{l}1 \\
1 \\
1 \\
6\end{array}$ & $\begin{array}{r}65.80 \\
3.97 \\
37.10\end{array}$ & $\begin{array}{l}7.10 \\
0.43 \\
4.00\end{array}$ & $\begin{array}{l}0.037 \\
0.537 \\
0.092\end{array}$ \\
\hline Basalt vs. granite soils & $\begin{array}{l}\text { season } \\
\text { geology } \\
\text { season } \times \text { geology } \\
\text { error }\end{array}$ & 25 & $\begin{array}{r}1 \\
1 \\
1 \\
21\end{array}$ & $\begin{array}{r}88.59 \\
3.67 \\
38.85\end{array}$ & $\begin{array}{r}10.14 \\
0.42 \\
4.45\end{array}$ & $\begin{array}{l}0.004 \\
0.524 \\
0.047\end{array}$ \\
\hline
\end{tabular}




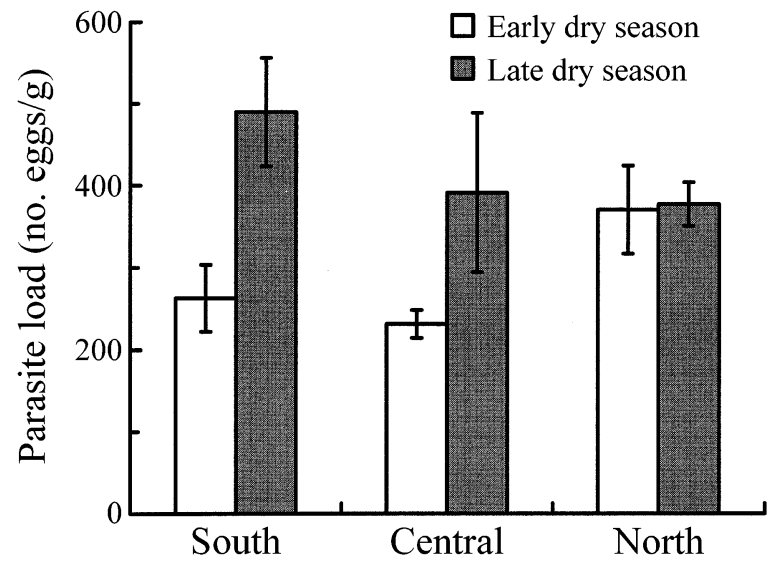

FIG. 5. Endoparasite loads of buffalo herds in early and late phases of the dry season in the northern, central, and southern regions of Kruger, as indicated by mean fecal egg counts ( $\pm 1 \mathrm{SE})$.

body condition, with faster rates of condition loss through the dry season, from the north to the south of the park (Table 1, Fig. 3). In the absence of BTB we would expect the opposite trend, because in the northern region annual rainfall is lower and more variable (Gertenbach 1983) and buffalo density is higher than in the south (unpublished Kruger monitoring data). At the herd level we also found that animals in herds with high BTB prevalence were in worse condition and lost condition faster than those in herds of medium or zero prevalence (Table 1, Fig. 4). The interaction of seasonal phase and BTB prevalence remained significant when we controlled for regional effects by restricting the analysis to just the southern and central regions. Because body condition may be confounded by age and sex we also restricted our analysis to females in $>5$ yr classes, although we found the same pattern of decreasing body condition with increasing BTB prevalence when we combined the data from all age classes. Our findings provide compelling evidence that body condition of Kruger buffaloes is significantly related to BTB prevalence, even though BTB has not yet had an apparent effect on population structure.

Rodwell et al. (2001) found only minor effects of BTB on the age structure of the Kruger buffalo population and no effect of BTB on the fertility and lactation of females. We found a significant regional variation in age structure, particularly in the 1-3 yr class, which may suggest a reduction in calf survival caused by a decrease in body condition of adult females and a subsequent decrease in milk production (Markusfeld et al. 1997, Hernandez and Baca 1998). Within regions, we found no statistically significant variation in age structure across herds with different BTB prevalence. Rodwell et al. (2001) found an underrepresentation of old buffalo in the south, possibly because of BTBinduced mortality in older individuals. We did not detect a similar effect with a sample size of more than
3000 animals ( $>10 \%$ of Kruger's total buffalo population), but we could not partition the adult age category as finely as did Rodwell et al. (2001) because our age estimates were based on visual characteristics rather than tooth eruption and wear. The results of our study nevertheless agree with those of Rodwell et al. (2001) in that the direct effects of BTB appear to be either slow or minor at the population level. Future studies on the effects of BTB should focus on the survival rates of individuals of known BTB status.

The results of our endoparasite analyses confirmed expectations from our body condition analyses in that fecal egg counts in the southern region increased more sharply through the dry season than they did in the northern region (Fig. 5, Table 2). Furthermore, by the end of the dry season, egg counts were significantly related to body condition (Fig. 6). This result may also be linked to BTB prevalence because we found that, within regions, egg counts increased more in herds of high BTB prevalence compared to herds with low BTB prevalence. In summary, herds with the highest BTB prevalence exhibited the greatest decline in body condition and a corresponding increase in fecal egg counts (Table 2).

These results agree with recent studies on the relationship between helminth and TB infections, which have found that a host's type-1 immune response to TB infection and nonpathogenic mycobacteria suppresses the type-2 immune response for controlling helminth infection (Abbas et al. 1996, Shirakawa et al. 1997, Erb et al. 1998, Wang and Rook 1998, Adams et al. 1999, Bentwich et al. 1999). Therefore, a high prevalence of BTB infection may inhibit type-2 immune responses resulting in high endoparasite loads at the herd level. Further studies need to be conducted to determine causality and whether antihelminthic drugs may affect BTB infection or the efficacy of vaccina-

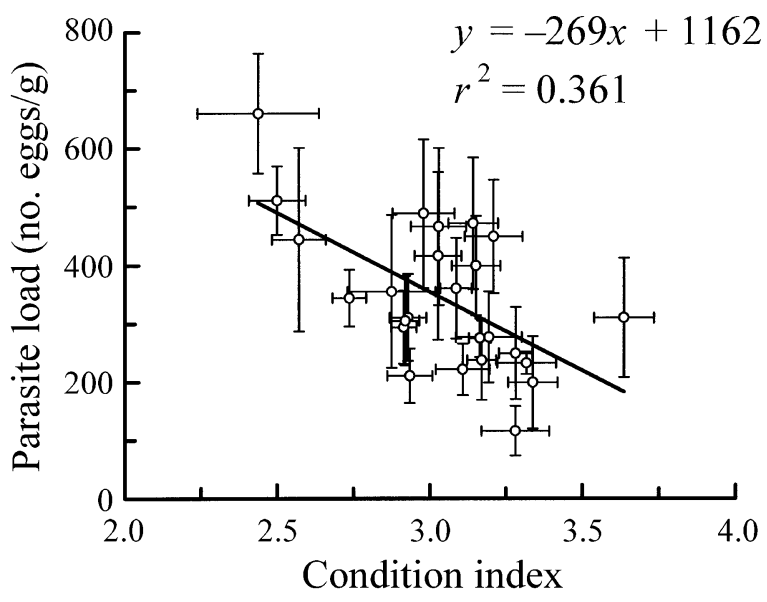

FIG. 6. Endoparasite load as a function of buffalo body condition at the herd level $(P<0.001)$. The condition index $(1=$ very poor; $5=$ good $)$ was based upon a visual assessment of females in the $>5-y r$ age classes. Data points are means $( \pm 1 \mathrm{SE})$ of each variable for samples from each herd. 
tions such as Bacillus Calmette-Guerin (BCG) in the buffalo population.

We acknowledge the controversy in the literature over the relationship between endoparasite egg counts and body condition (in favor: Bekele et al. 1991, Hoste and Chartier 1993; against: Keith et al. 1986, Wolkers et al. 1994, Gallivan et al. 1996, Zaffaroni et al. 1997) but we also note that endoparasites may reduce egg production during the dry season when the chances of completing their life cycles are reduced (Jacquiet et al. 1995, Ndao et al. 1995). Consequently an increase in egg counts through the dry season, such as we found, could reflect a disproportionate increase in parasite load. Our Kruger buffalo data are consistent with the expectation that body condition would decline when endoparasite loads increase, and this would occur when the animal's ability to withstand its parasite challenge is compromised by nutritional stress and disease (Murray et al. 1998).

Human studies on the links between tuberculosis, malnutrition, and body condition (e.g., Harries et al. 1988, Onwubalili 1988, Scalicini et al. 1991, Macallan 1999) indicate that malnutrition and tuberculosis can both decrease body condition independently, but a decrease in body condition increases the risk of developing tuberculosis. We cannot determine the strength of each pathway from our correlational study, but our findings on the Kruger buffalo population do indicate that BTB is operating in synergy with parasitism and resource limitation to significantly reduce body condition through the dry season. This implied effect of BTB on buffalo morbidity does not yet appear to have impacted on the population's age structure, but there are broader ecological implications to consider. First, our finding that herds with high BTB prevalence undergo the greatest loss of body condition during the dry season indicates that BTB could exacerbate the effects of future droughts on the buffalo population. Second, buffaloes in Kruger are preyed on mainly by lions, which target animals in poor condition because they are easiest to kill (Mills et al. 1995, Funston 1998). From the association between BTB prevalence and body condition that we have demonstrated for Kruger buffaloes, it follows that each lion pride must be killing and consuming a higher proportion of BTB infected animals than would be found living in the nearest herd. It has been demonstrated that various carnivores in Kruger are susceptible to BTB, especially lions (Keet et al. 1996), and so the ecological implications of the BTB epidemic in the buffalo population should also be considered further up the food chain.

\section{ACKNOWLEDGMENTS}

Funding for this research came from the National Science Foundation, USA (Ecology of Infectious Diseases Grant DEB-0090323 to Wayne Getz) and the National Research Foundation, South Africa (Grant GUN-2050431 to Johan du Toit). We are grateful to South African National Parks for allowing this research to be conducted, and in particular to
Markus Hofmeyr for his assistance. Justin Bowers, Kutani Bulunga, Craig Hay, and Augusta Mabunda provided invaluable assistance in the field. A previous version of the manuscript was improved by constructive comments from Richard Ostfeld and two anonymous referees.

\section{Literature Cited}

Abbas, A. K., K. M. Murphy, and A. Sher. 1996. Functional diversity of helper T lymphocytes. Nature 383:787-793.

Adams, J. F. A., E. H. Schölvinck, R. P. Gie, P. C. Potter, N. Beyers, and A. D. Beyers. 1999. Decline in total serum IgE after treatment for tuberculosis. Lancet 353:20302033.

Basson, P. A., R. M. McCully, S. P. Kruger, J. W. van Niekerk, E. Young, and V. de Vos. 1970. Parasitic and other diseases of the African buffalo in the Kruger National Park. Onderstepoort Journal of Veterinary Research 37:11-28.

Bekele, T., O. B. Kasali, and J. E. Rege. 1991. Repeatability of measurements of packed cell volume and egg count as indicators of endoparasite load and their relationship with sheep productivity. Acta Tropica 50:151-160.

Bengis, R. G., C. C. Grant, and V. de Vos. 2003. Wildlife diseases and veterinary controls. In J. T. du Toit, H. Biggs, and K. H. Rogers, editors. The Kruger experience: ecology and management of savanna heterogeneity. Island Press, Washington, D.C., USA, in press.

Bengis, R. G., N. P. J. Kriek, D. F. Keet, J. P. Raath, V. de Vos, and H. F. K. A. Huchzermeyer. 1996. An outbreak of bovine tuberculosis in a free-living African buffalo (Syncerus caffer-Sparrman) population in the Kruger National Park-A preliminary report. Onderstepoort Journal of Veterinary Research 63:15-18.

Bentwich, Z., A. Kalinkovich, Z. Weisman, G. Borkow, N. Beyers, and A. D. Beyers. 1999. Can eradication of helminthic infections change the face of AIDS and tuberculosis? Immunology Today 20:485-487.

Bruning-Fann, C. S., S. M. Schmitt, S. D. Fitzgerald, J. B. Payeur, D. L. Whipple, T. M. Cooley, T. Carlson, and P. Friedrich. 1998. Mycobacterium bovis in coyotes from Michigan. Journal of Wildlife Diseases 34:632-636.

de Vos, V., R. G. Bengis, N. P. J. Kriek, A. Michel, D. F. Keet, J. P. Raath, and H. F. K. A. Huchzermeyer. 2001. The epidemiology of tuberculosis in free-ranging African buffalo (Syncerus caffer) in the Kruger National Park, South Africa. Onderstepoort Journal of Veterinary Research 68:119-130.

Erb, K. J., J. W. Holloway, A. Sobeck, H. Moll, and G. Le Gros. 1998. Infection of mice with Mycobacterium bovisBacillus Calmette-Guérin (BCG) suppresses allergen-induced airway eosinophilia. Journal of Experimental Medicine 187:561-569.

Funston, P. 1998. Predator-prey relationships between lions and large ungulates in the Kruger National Park. Ph.D. thesis. University of Pretoria, Pretoria, South Africa.

Gallivan, G. J., I. K. Barker, J. Culverwell, and R. Girdwood. 1996. Prevalence of hepatic helminths and associated pathology in impala (Aepyceros melampus) in Swaziland. Journal of Wildlife Diseases 32:137-141.

Gertenbach, W. P. D. 1983. Landscapes of the Kruger National Park. Koedoe 26:9-121.

Grimsdell, J. J. R. 1973. Age determination of the African buffalo, Syncerus caffer-Sparrman. East African Wildlife Journal 11:31-53.

Harries, A. D., W. A. Nkhoma, P. J. Thompson, D. S. Nyangulu, and J. J. Wirima. 1988. Nutritional status in Malawian patients with pulmonary tuberculosis and response to chemotherapy. European Journal of Clinical Nutrition 42:445450.

Hernandez, J., and D. Baca. 1998. Effect of tuberculosis on milk production in dairy cows. Journal of American Veterinary Medical Association 213:851-854. 
Hoste, H., and C. Chartier. 1993. Comparison of the effects on milk production of concurrent infection with Haemonchus contortus and Trichostrongylus colubriformis in highand low-producing dairy goats. American Journal of Veterinary Research 54:1886-1893.

Jacquiet, P., F. Colas, J. Cabaret, M. L. Dia, D. Cheukh, and A. Thiam. 1995. Dry areas: an example of seasonal evolution of helminth infection of sheep and goats in southern Mauritania. Veterinary Parasitology 56:137-148.

Kao, R. R., and M. G. Roberts. 1999. A comparison of wildlife control and cattle vaccination as methods for the control of bovine tuberculosis. Epidemiology and Infection 122: 509-519.

Keet, D. F., N. P. J. Kriek, R. G. Bengis, D. G. Grobler, and A. Michel. 2000. The rise and fall of tuberculosis in a freeranging chacma baboon troop in the Kruger National Park. Onderstepoort Journal of Veterinary Research 67:115-122.

Keet, D. F., N. P. J. Kriek, R. G. Bengis, and A. Michel. 2001. Tuberculosis in kudus (Tragelaphus strepsiceros) in the Kruger National Park. Onderstepoort Journal of Veterinary Research 68:225-230.

Keet, D. F., N. P. J. Kriek, M. L. Penrith, A. Michel, and H. Huchzermeyer. 1996. Tuberculosis in buffaloes (Syncerus caffer) in the Kruger National Park: spread of the disease to other species. Onderstepoort Journal of Veterinary Research 69:239-244.

Keith, I. M., L. B. Keith, and J. R. Cary. 1986. Parasitism in a declining population of snowshoe hares. Journal of Wildlife Diseases 22:349-363.

Krebs, J. R., R. M. Anderson, T. Clutton-Brock, C. A. Donnelly, S. Frost, W. I. Morrison, R. Woodroffe, and D Young. 1998. Badgers and bovine TB: conflicts between conservation and health. Science 279:817-818.

Macallan, D. C. 1999. Malnutrition in tuberculosis. Diagnostic Microbiology and Infectious Disease 34:153-157.

Markusfeld, O., N. Galon, and E. Ezra. 1997. Body condition score, health, yield and fertility in dairy cows. Veterinary Record 141:67-72

Mills, M. G. L., H. C. Biggs, and I. J. Whyte. 1995. The relationship between rainfall, lion predation and population trends in African herbivores. Wildlife Research 22:75-88.

Morris, R. S., D. U. Pfeiffer, and R. Jackson. 1994. The epidemiology of Mycobacterium bovis infections. Veterinary Microbiology 40:153-177.

Mosugelo, D. K., S. R. Moe, S. Ringrose, and C. Nelleman. 2002. Vegetation changes during a 36-year period in northern Chobe National Park, Botswana. African Journal of Ecology 40:232-240.

Murray, D. L., L. B. Keith, and J. R. Cary. 1998. Do parasitism and nutritional status interact to affect production in showshoe hares? Ecology 79:1209-1222.

Ndao, M., V. S. Pandey, J. Zinsstag, and K. Pfister. 1995. Helminth parasites and hypobiosis of nematodes in N'Dama cattle during the dry season in The Gambia. Veterinary Parasitology 60:161-166.

Onwubalili, J. K. 1988. Malnutrition among tuberculosis patients in Harrow, England. European Journal of Clinical Nutrition 42:363-366.
Pienaar, U. de V. 1969. Observations on developmental biology, growth and some aspects of the population ecology of African buffalo (Syncerus caffer caffer Sparrman). Koedoe 12:29-52.

Prins, H. H. T. 1996. Ecology and behaviour of the African buffalo. Chapman and Hall, London, UK.

Raynaud, J. P. 1970. Etude de l'efficacité d'une technique de coproscopie quantitative pour le diagnostic de routine et le contrôle des infestations parasitaires des bovins, ovins, equins et porcins. Annales de Parasitologie Humaine et Comparée 45:321-342.

Rodwell, T. C., N. P. Kriek, R. G. Bengis, I. J. Whyte, P. C. Viljoen, V. de Vos, and W. M. Boyce. 2000. Prevalence of bovine tuberculosis in African buffalo at Kruger National Park. Journal of Wildlife Diseases 37:258-264.

Rodwell, T. C., I. J. Whyte, and W. M. Boyce. 2001. Evaluation of population effects of bovine tuberculosis in freeranging African buffalo (Syncerus caffer). Journal of Mammalogy 82:231-238.

Scalicini, M., R. Occenac, J. Manfreda, and R. Long. 1991. Pulmonary tuberculosis, human immunodeficiency virus type-1a, human immunodeficiency virus type-1 and malnutrition. Bulletin of the International Union Against Tuberculosis and Lung Disease 66:37-41.

Schmitt, S. M., S. D. Fitzgerald, T. M. Cooley, C. S. BruningFann, L. Sullivan, D. Berry, T. Carlson, R. B. Minnis, J. B. Payeur, and J. Sikarskie. 1997. Bovine tuberculosis in free-ranging white-tailed deer from Michigan. Journal of Wildlife Diseases 33:748-758.

Shirakawa, T., T. Enomoto, S. Shimazu, and J. M. Hopkin. 1997. The inverse association between tuberculin responses and atopic disorder. Science 275:77-79.

Sinclair, A. R. E. 1977. The African buffalo: a study of resource limitation of population. University of Chicago Press, Chicago, Illinois, USA.

Sinclair, A. R. E. 1979. Dynamics of the Serengeti ecosystem. Pages 1-30 in A. R. E. Sinclair and M. Norton-Griffiths, editors. Serengeti: dynamics of an ecosystem. University of Chicago Press, Chicago, Illinois, USA.

StatSoft. 1991. Statistica. StatSoft, Tulsa, Oklahoma, USA.

Thienpont, D., F. Rochette, and O. F. J. Vanparils. 1986. Diagnosing helminthiasis by coprological examination. Janssen Research Foundation, Beerse, Belgium.

Walker, B. 1989. Diversity and stability in ecosystem conservation. Pages 121-130 in D. Western and M. Pearl, editors. Conservation for the 21 st century. Oxford University Press, Oxford, UK.

Wang, C. C., and G. A. Rook. 1998. Inhibition of an established allergic response to ovalbumin in BALB/c mice by killed Mycobacterium vaccae. Immunology 93:307-313.

Ward, M. P., M. Lyndal-Murphy, and F. C. Baldock. 1997. Evaluation of a composite method for counting helminth eggs in cattle faeces. Veterinary Parasitology 73:181-187.

Wolkers, J., T. Wensing, G. W. Groot Bruinderink, and J. T. Schoneville. 1994. Lungworm and stomach worm infection in relation to body fat reserves and blood composition in wild boar (Sus scrofa). Veterinary Quarterly 16:193-195.

Zaffaroni, E., C. Citterio, M. Sala, and S. Lauzi. 1997. Impact of abomasal nematodes on roe deer and chamois body condition in an alpine environment. Parasitologia 39:313-317. 